\title{
Understanding differences between summer vs. school obesogenic behaviors of children: the structured days hypothesis
}

Keith Brazendale ${ }^{1 *}$ (D, Michael W. Beets ${ }^{1}$, R. Glenn Weaver ${ }^{1}$, Russell R. Pate ${ }^{1}$, Gabrielle M. Turner-McGrievy², Andrew T. Kaczynski ${ }^{2}$, Jessica L. Chandler ${ }^{3}$, Amy Bohnert ${ }^{4}$ and Paul T. von Hippel ${ }^{5}$

\begin{abstract}
Background: Although the scientific community has acknowledged modest improvements can be made to weight status and obesogenic behaviors (i.e., physical activity, sedentary/screen time, diet, and sleep) during the school year, studies suggests improvements are erased as elementary-age children are released to summer vacation. Emerging evidence shows children return to school after summer vacation displaying accelerated weight gain compared to the weight gained occurring during the school year. Understanding how summer days differ from when children are in school is, therefore, essential.

Discussion: There is limited evidence on the etiology of accelerated weight gain during summer, with few studies comparing obesogenic behaviors on the same children during school and summer. For many children, summer days may be analogous to weekend days throughout the school year. Weekend days are often limited in consistent and formal structure, and thus differ from school days where segmented, pre-planned, restrictive, and compulsory components exist that shape obesogenic behaviors. The authors hypothesize that obesogenic behaviors are beneficially regulated when children are exposed to a structured day (i.e., school weekday) compared to what commonly occurs during summer. This is referred to as the 'Structured Days Hypothesis' (SDH). To illustrate how the SDH operates, this study examines empirical data that compares weekend day (less-structured) versus weekday (structured) obesogenic behaviors in U.S. elementary school-aged children. From 190 studies, 155 ( 80\%) demonstrate elementary-aged children's obesogenic behaviors are more unfavorable during weekend days compared to weekdays.

Conclusion: In light of the SDH, consistent evidence demonstrates the structured environment of weekdays may help to protect children by regulating obesogenic behaviors, most likely through compulsory physical activity opportunities, restricting caloric intake, reducing screen time occasions, and regulating sleep schedules. Summer is emerging as the critical period where childhood obesity prevention efforts need to be focused. The SDH can help researchers understand the drivers of obesogenic behaviors during summer and lead to innovative intervention development.
\end{abstract}

Keywords: Children, Obesity, School, Summer

\footnotetext{
* Correspondence: brazendk@email.sc.edu

'Department of Exercise Science, Arnold School of Public Health, University

of South Carolina, 921 Assembly Street, 1st Floor Suite, Room 131, Columbia,

SC 29208, USA

Full list of author information is available at the end of the article
} 


\section{Background}

In the United States (U.S.), the prevalence of obesity among children aged 6-11 years has increased substantially in the last five decades [1], with the most recent estimates indicating $31.8 \%$ of children and adolescents aged 2-19 years are classified as either overweight or obese [2]. Children who are overweight or obese are at an increased risk for developing non-communicable diseases [3], thereby establishing childhood obesity as an immediate public health concern $[4,5]$. Intervention strategies targeting obesity prevention among youth have focused primarily on four obesogenic behaviors: increasing physical activity (PA), decreasing sedentary/screen time, and improving dietary intake and sleep length and patterns. There is consistent evidence that these behaviors, alone or in combination, are associated with unwanted weight-gain in children [6-9].

The majority of the literature describing or intervening on 'obesogenic behaviors' of youth has been conducted during the 9-month school year, hereon referred to as 'school'. The rationale for this is straightforward - over $90 \%$ of youth in the US attend public or private schools for approximately $6 \mathrm{~h}$ each day, 180 days of the year [5]. However, a number of recent studies consistently show that when children return to school after summer they display accelerated weight gains compared to the weight gain occurring during the school year $[6,10-15]$. In addition, children display a loss in cardio-respiratory fitness (CRF) over the summer compared to the school year $[16,17]$. These negative health outcomes are more pronounced in children who are already overweight or obese, of ethnic minority, and from low socio-economicstatus (SES) households [11].

Investigations into the causal factors associated with the accelerated weight gain and loss in CRF during summer are limited and report mixed findings [13, 18, 19]. Studies report that children are more active [19], while others report they are less active during summer compared to school [13]. Studies report children have higher screen time during summer compared to school $[18,20]$, have less favorable diets or similar dietary intake during summer compared to school [13, 19], and sleep either the same amount [18] or slightly less [21] during summer compared to school. These studies were limited by study-design (e.g., between-subjects), definitions of "summer" (e.g., summer, winter, and holiday break data combined), obesogenic behavior assessment (e.g., selfreport measures), and/or sample size (e.g., repeated measures on 14 children). These limitations prohibit the understanding of the causal factors associated with the occurrence of accelerated weight gain during summer.

Although convincing evidence documents the accelerated weight gain and loss of fitness during summer, there is currently a lack of frameworks or working hypotheses articulating the substantive differences between summer versus the school year that may lead to negative health outcomes. Conceptually, a fundamental difference in a child's day during the school year versus summer is the presence of a consistent, structured, less autonomous (compared to summer), and segmented day with adult supervision. School days are an example of an ever-present structured environment with purposive, segmented, restrictive, and compulsory components. Conversely, summer days, for the most part, can be viewed as an environment with less formal structure and a higher degree of open-endedness. Subsequently, a more autonomous environment (e.g., summer) provides children with greater choice and the environment within which greater choice may exist - such as the home environment - has both physical and social aspects that can negatively influence a child's weight status, particularly in children from low-income households [22, 23]. On the contrary, it must be noted that children are not without choice during more structured and regulated environments, like a school day; and research shows how children will select the less-healthful option (e.g., unhealthy snack), knowingly so [24], in light of a more health-enhancing option [25].

In absence of a extensive literature base to draw from that investigates summer and school differences, we propose that a day during the summer can be considered analogous to a weekend day during the school year. Although weekends are shorter in duration in comparison to summer, they possess similarities in that children are largely free from segmented, restrictive, and compulsory daily components (compared to what school demands) and allowed to make more autonomous choices in their behaviors. Thus, identifying children's obesogenic behaviors during a less-structured day (weekend day) during the school year and comparing this in relation to a structured day (weekday) might shed light on what occurs over the summer. Further, it is plausible that, in comparison to school, a more autonomous and unhealthier home environment operates, and, thus, allows children to self-select and indulge in a variety of unhealthy behaviors of which, compounded over an uninterrupted 3-month period, results in adverse health outcomes (e.g., accelerated weight gain) that are not manifested during weekends during the 9-months of the school year due to the shorter duration of this time period.

In this debate article, the authors put forward the 'Structured Days Hypothesis' (SDH) which is founded on the premise that a structured day (represented herein by a school day), defined as a pre-planned, segmented, and adult supervised compulsory environment, plays an overall protective role for children against obesogenic behaviors, and, ultimately, prevents the occurrence of negative health-outcomes, in this case excessive weight 
gain and loss in CRF. Equally, the absence of 'structure' to summer days could be one of the reasons children return to school, after summer break, with accelerated weight gain and decreases in CRF. Within the confines of the SDH, the authors present the scientific evidence on PA, sedentary/screen time, diet, and sleep in relation to the larger literature base that compares weekdays versus weekend days - two contexts considered structured and less-structured environments, respectively.

\section{The 'structured days hypothesis' (SDH)}

In the $\mathrm{SDH}$, it is hypothesized that the consistent presence of structure, routine, and/or regulation within a day positively shapes the obesogenic behaviors of youth. It must be noted that structure, regulation, and/or routine is neither a novel concept nor a new experience for children, as children are exposed to such traits on a dayto-day basis for the majority of the calendar year (i.e., a school day). Further, the SDH draws from concepts found in the 'filled-time perspective' which is based on the principal that time filled with favorable activities cannot be filled with unfavorable activities [26]. This applies to the SDH where structure, routine, compulsory, and/or regulation - common characteristics of a school day - fills children's time with 'favorable activities' such as scheduled PA opportunities (e.g., school PE, recess) and regulated caloric intake (e.g., school meal programs) and set meal/snack times. Figure 1 illustrates a conceptual model of the SDH. During summer, the SDH proposes there is less structure, routine, and/or regulation, and more autonomy for children during summer afforded in the home environment. This leaves more time that can be filled with unfavorable activities/behaviors that are more prevalent in the home environment, such as extended periods of sedentary/screen time and/ or liberties to choose when, what, and how much to eat/ drink [22, 23, 27]. Importantly, during less-structured environments unfavorable activities can displace favorable activities (e.g., children choose sedentary pursuits over PA) and co-occur (e.g., snacking whilst watching TV). In addition, structured days (i.e., a school day) provide all children with opportunities and exposure to more favorable obesogenic behaviors (e.g., PA opportunities, restricted screen time), and a lower degree of child autonomy (e.g., limited eating occasions and choice of foods/beverages) compared to less-structured days (i.e., a summer day). Using the school day as an example of a structured environment, the proposed mechanisms for how the SDH operates across PA, sedentary/screen time, sleep, and diet, are detailed below. A summary is also provided in Table 1.

1. Physical Activity: The authors hypothesize school days (i.e., typical weekday) are fundamentally different from less-structured days, such as a weekend day or summer days, due to the fact that they consistently contain a daily structure and routine with intentional (e.g., recess, physical education, before/after school

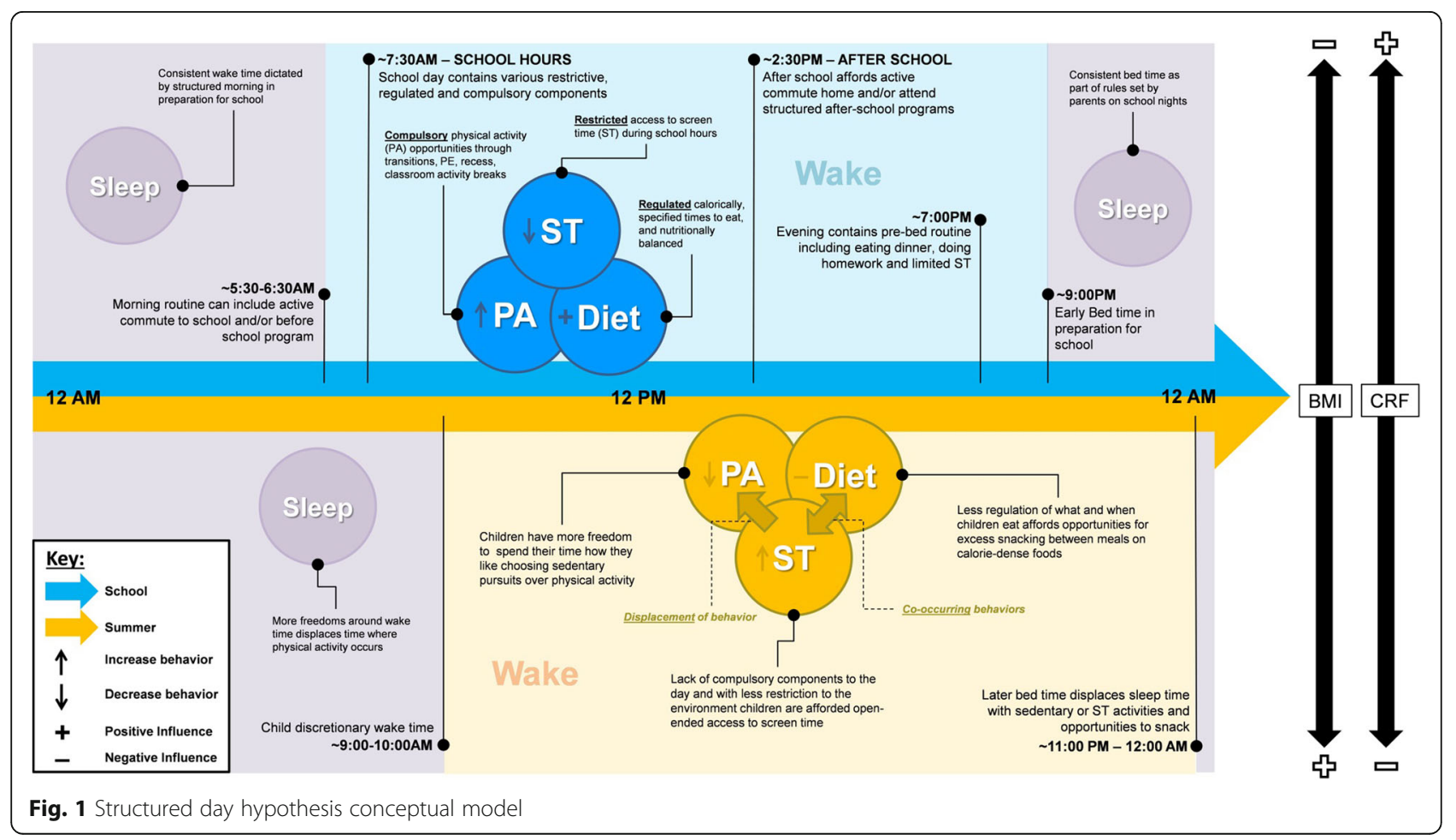


Table 1 How Structured Days Hypothesis (SDH) operates across obesogenic behavior

\begin{tabular}{|c|c|c|c|}
\hline Obesogenic Behavior & $\begin{array}{l}\text { Protective Element of 'Structured' } \\
\text { School Day }\end{array}$ & $\begin{array}{l}\text { Impact on Obesogenic } \\
\text { Behavior }\end{array}$ & School Example(s) \\
\hline Physical Activity & $\begin{array}{l}\text { Compulsory and voluntary PA } \\
\text { opportunities for physical activity } \\
\text { to occur before, during, and/or } \\
\text { after school. }\end{array}$ & Increased daily PA & $\begin{array}{l}\text { - Walking to/from school } \\
\text { - Recess } \\
\text { - Physical education } \\
\text { - Transitions between class/activities } \\
\text { - Classroom PA Promotion } \\
\text { - Before/after-school programs or sports } \\
\text { clubs }\end{array}$ \\
\hline Sedentary/Screen Time & $\begin{array}{l}\text { Segmented school day limits } \\
\text { amount of time children spend } \\
\text { seated. Limited non-educational } \\
\text { screen time. }\end{array}$ & $\begin{array}{l}\text { Decreased daily sedentary/ } \\
\text { screen time }\end{array}$ & $\begin{array}{l}\text { - Bouts of sedentary time broken-up by } \\
\text { transitions in and to/from class } \\
\text { - Classroom teachers control screen time } \\
\text { exposure }\end{array}$ \\
\hline Sleep & $\begin{array}{l}\text { Presence of school day establishes } \\
\text { consistent early bed/wake times } \\
\text { for children and evening/morning } \\
\text { routines and rules. }\end{array}$ & Earlier bed/wake times & $\begin{array}{l}\text { - Parent/Guardian enforces earlier bed/wake } \\
\text { time rules on school days } \\
\text { - Child is awake earlier to engage in morning } \\
\text { intentional and unintentional PA } \\
\text { - Early bed time reduces child engagement in } \\
\text { sedentary/screen time }\end{array}$ \\
\hline Diet & $\begin{array}{l}\text { Structure of school day limits eating } \\
\text { occasions for children. Schools offer } \\
\text { regulated access to nutrient dense } \\
\text { meals. }\end{array}$ & $\begin{array}{l}\text { Decreased access to unhealthy } \\
\text { foods/beverages and reduced } \\
\text { overconsumption }\end{array}$ & $\begin{array}{l}\text { - Scheduled opportunities to consume foods/ } \\
\text { beverages in school (e.g., breakfast, recess, lunch). } \\
\text { - NSLP serve nutritionally balanced, age-appropriate } \\
\text { portions. }\end{array}$ \\
\hline
\end{tabular}

programs, organized sports programs) and unintentional (e.g., regular transitions between activities, walking to school) PA opportunities provide to the majority of children through the school day [28]. For example, a child may be exposed to all or a combination of some of the following on a school day; a morning commute to school, recess, physical education, lunch recess, after school program or activity, organized sport program, and a commute home from school [29]. Hypothetically, during less-structured days there may be less daily pre-planned PA opportunities for children, and the less-structured nature of the day itself reduces the occurrence of unintentional PA opportunities. Further, increased autonomy during less-structured days may allow children to choose to sedentary pursuits over physical activity (displacement).

2. Sedentary/Screen Time: The authors hypothesize the routine structure of a school day limits the amount of time children can spend sedentary, such as when watching TV or playing video games. Although children can spend a large amount of time sitting during the school day, bouts of time spent sedentary are broken-up by transitions during the segmented day and by planned opportunities where minimal sedentary time can occur (e.g., physical education, recess) [30]. Conversely, during lessstructured days - where there may be less regulation or restriction -children may be exposed to increased unsupervised and open-ended periods of time where they are free to indulge in sedentary activities, such as TV viewing and playing computer games [11, 12]. In addition, co-occurring unfavorable behaviors are freer to operate, such as snacking whilst watching TV.

3. Sleep: The authors hypothesize the presence of the structured school day plays a role in minimizing the shift of bed/wake times. Specifically, children are going to bed earlier and waking earlier during school days, which studies have found is more beneficial to a child's weight status than a late bedtime/late waketime [31]. For example, on a night that precedes a school day there is more likely to be a consistent bed-time and corresponding wake-time, followed by a typical morning routine (i.e., structure). This is incidentally enforced as a result of the presence of the school day. During a less-structured day, such as summer, there may be less structure in a child's morning and evening periods; where children may be given more freedoms to stay up later in the evening and wake later in the morning. The later bed and wake times displace time that could be spent engaging in favorable obesogenic behaviors such as sleep in the evening, and PA in the morning, respectively.

4. Diet: The authors hypothesize children have limited opportunities to eat/drink during the school day [12] and access to regulated food programs $[11,15]$ that provide nutrient dense meals that meet existing federal nutrition guidelines [32]. Conversely, less-structured days (e.g., weekend day, summer day) may be giving children increased opportunities to snack and access to unhealthier foods in the home. As summer may present an open-ended and autonomous environment 
for children, other factors could drive increased energy intake during summer such as increased snacking of calorie-dense low nutrient foods whilst engaging in screen time activities for extended periods of time (co-occurring behavior) [33, 34].

To support these hypotheses, a systematic search following the PRISMA guidelines [35] of published studies reporting week day and weekend day obesogenic behaviors of elementary-age children ages 5 to 11 years was conducted. A separate search, using PubMed, Google Scholar, and Web of Science, was performed for each of the following obesogenic behaviors: PA, sedentary, screen time, sleep, and diet. The following key words and/or search terms were used: "physical activity" sedentary", screen", television", sleep", diet", nutrition*. Each of these individual terms were followed by weekday* week$e d^{*}$ and child*. Studies were excluded if they investigated a different population (e.g., adolescents, adults, children with disabilities), did not report weekend versus weekday outcomes, and/or were not published in English. Studies reporting outcome data of children that incorporated other ages outside 5-11 year old range were included as long as data were segmented by age group/ category. Included studies were stratified by country (U.S. or International) and whether or not a statistical test was carried out on the difference between the weekday and weekend day outcome (statistical test or no test). Studies showing statistically significant (as defined within each study) favorable outcomes (e.g., increased PA, reductions in sedentary/screen time, earlier bed/wake times, and lower consumption/frequency of consumption of unhealthy foods/drinks) during weekdays (i.e., structured days) compared to weekend days (i.e., less-structured days) were classified as for the SDH. If a study reported outcomes that did not align with the above criteria (e.g., Weekend days more favorable than weekdays or no difference) was classified as against the SDH. Table 2 presents the number of studies found, excluded, and if the weekend day versus weekday outcome was for or against the SDH.

\section{Results}

In total, 867 studies were screened for inclusion. Based on the exclusion criteria, 677 studies were removed because of sample population $(n=454)$, omission of a weekend vs weekday outcome $(n=198)$, or not published in English $(n=25)$. Of the remaining studies included for assessment $(n=190)$, there was no indication of patterns or groupings for studies that were categorized as either for or against the SDH in terms of study characteristics (e.g., method of obesogenic behavior measurement, sample size, country/continent of origin).

\section{Physical activity}

A total of 91 studies reported weekend day and weekday PA estimates, with 18 originating from the U.S. [36-53]. Of these, $81 \%$ reported findings supporting the SDH. Two recent U.S. based studies employing objective measures of PA concluded that accumulated MVPA was higher on weekdays compared to weekend days. The first study explored 187 2nd and 3rd grade children's (48.7\% boys) MVPA on weekdays and weekend days using 5 days of accelerometer assessment. The authors reported that children's MVPA was greater during weekdays (46.0 $\mathrm{min} /$ day) compared with weekend days (37.7 $\mathrm{min} /$ day) [36]. Another accelerometer-based study examined disparities in MVPA among overweight and obese 3rd - 5th grade children. Children classified as Overweight or Obese accumulated 11 min less of MVPA on weekend days compared with weekdays $(p<0.05)$ [37]. Similar trends have been found in the PA literature when using different objective measures of PA (e.g., pedometers [43, 44, 49]), self-report measures of PA [50], and investigating girls PA patterns [39, 54]. Further, a meta-analysis of objectively measured PA revealed school-aged children are more active on weekdays than weekend days (+14 MVPA min/day) [42].

Seventy three international studies were identified that report weekday and weekend day differences in PA $[29,55-120]$. Of these studies, $\sim 80 \%$ drew similar conclusions to the U.S literature, with 39 of these studies showing PA was lower on weekend days compared to weekdays reporting a statistically significant difference. One cohort study $(N=704)$ investigating seasonal variation in children's PA was conducted in the United Kingdom (UK) and reported that across all seasons, accumulation of MVPA was higher on weekdays compared with weekend days [55]. The authors suggested that PA during weekday is less likely to vary as the school day and its corresponding daily PA segments - are less likely to be influenced by seasonal changes, whereas weekend days are more susceptible to influence due to the volitional nature of PA opportunities. Another study measuring PA levels via accelerometry in a large sample of 11-year old children $(N=5595)$ found weekdays to be more active than weekend days $(+31 \mathrm{cpm})$ [29], and other accelerometer-based studies conducted across different continents (e.g., Canada [56], Sweden [57], and Singapore [58]) in varying samples of elementary school-aged children $(\mathrm{N} \sim 80$ to 1300) report MVPA is higher on weekdays compared to weekend days.

\section{Sedentary/screen time}

A total of 62 studies were identified reporting either sedentary and/or screen time estimates for elementary school-aged children. Of these $62, \sim 18 \%$ of studies were conducted in the U.S. [30,39,46, 47, 121-127], with the 


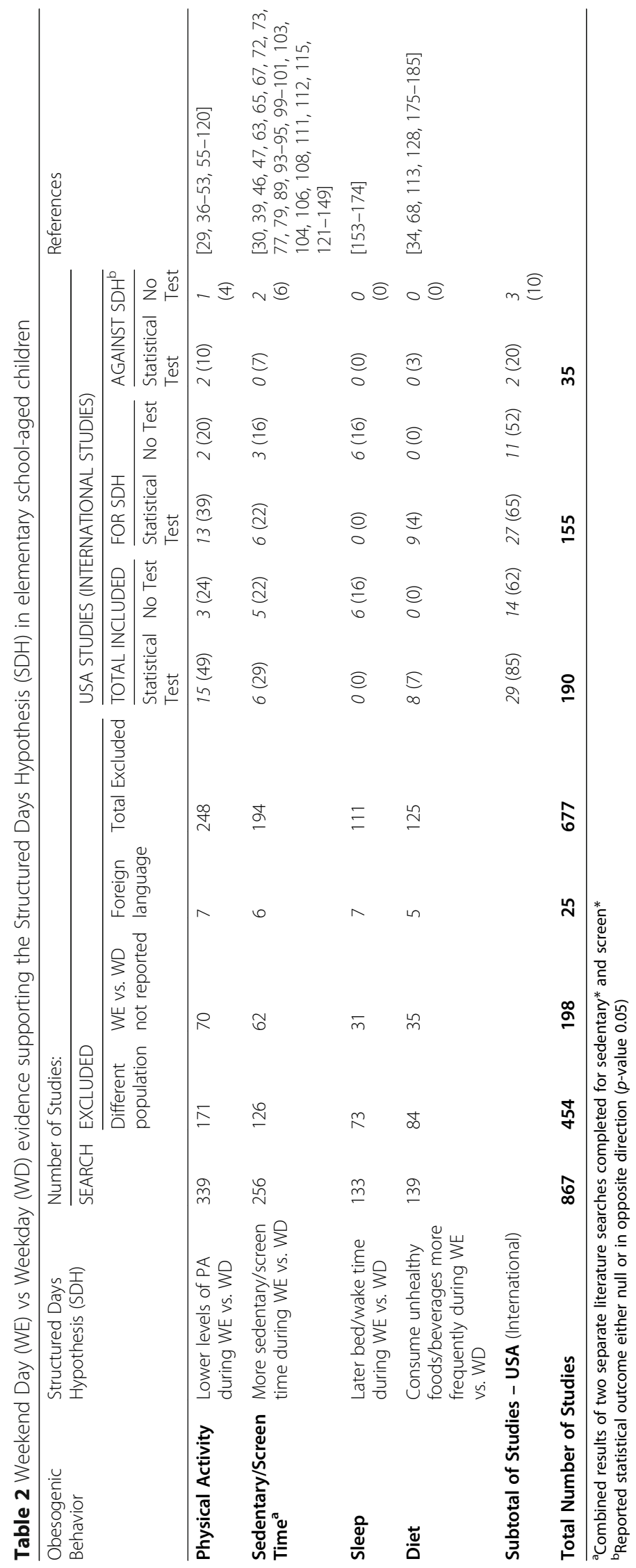


remaining studies from other countries $[63,65,67,72$, 73, 77, 79, 89, 93-95, 99-101, 103, 104, 106, 108, 111, $112,115,118,128-149]$. The majority of the sedentary/ screen time estimates reported in the literature came from self-report measures (e.g., surveys, questionnaires, recalls). An early U.S. study analyzed TV viewing data from the Panel Study of Income Dynamics (PSID; 1997), collected using 24-h time diaries completed by the primary caregiver (i.e., parent/guardian). The analysis of $\sim 1000$ boys and girls (6-12 years) reported TV viewing increased on average by 60 min per day during weekend days compared to weekdays [121]. Another study reported that during weekdays $82 \%$ of children $(N=245$; 6th to 8 th grade) watched $\leq 2 \mathrm{~h}$ per day of TV (screen time recommendation for US children) compared to $76 \%$ of children on weekend days during school [122]. This finding is in agreement with several other studies conducted outside the U.S. [101, 134, 142, 150-152]. For example, Jago et al. (2014) examined survey data from parents of 5-6 year old children $(N=1078)$ on several screen time behaviors (e.g., TV viewing, computer use, videogame consoles). The percent of children spending $\geq 2 \mathrm{~h}$ per day engaged in screen time increased by approximately $34 \%$ during weekend days compared to weekdays [134]. Another study of approximately 15,000 children across multiple European countries reported $52 \%$ of the sample engaged in $\geq 2 \mathrm{~h}$ per day of screen time on weekend days compared to $20 \%$ on weekdays [140].

Twenty six studies reported the amount of time children spend sedentary comparing weekdays versus weekend days using objective measures (e.g., accelerometers, pedometers etc.). Atkin et al. (2016) analyzed seasonal data of 700 elementary school-aged children from a UK cohort study and reported increased sedentary time on weekend days compared to weekdays in 3 out of the 4 seasons (range; 9-54 additional sedentary minutes per day on weekend days) [55]. Another study explored inschool versus out-of-school sedentary time patterns of 206 5th grade children across 10 elementary schools in Colorado. The authors concluded children spent more time sedentary during weekend days ( $+5 \%$ of wear time) compared with weekdays [30]. In agreement, additional accelerometer-based studies from Canada [130,132] and the United Kingdom $[65,108]$ concluded children spend statistically significantly more time sedentary on weekend days versus weekdays. Fifteen of the 62 studies found no difference in sedentary/screen time between weekend days and weekdays - or reported weekend days were less sedentary than weekdays.

\section{Sleep}

A total of 22 studies reported bed and wake times for elementary school-aged children during weekdays and weekend days. Of these studies, $\sim 27 \%$ were conducted within the U.S. [153-158], with the remaining $73 \%$ originating from other countries [159-174]. One of the earliest U.S. studies conducted by Blader and colleagues had parents of 978 5-12 year old children (85\% Caucasian) complete a 48-item survey. The authors reported weekend bed/wake-times were 45-60 min later compared to weekdays [153]. A more recent study explored a large nationally representative sample of 3-18 year old U.S. children $(N=2281)$ and reported a clear shift in sleep time, with children going to bed and waking later on weekend days compared to weekdays across the range of ages [154]. Studies conducted outside the U.S. show similar bed/wake time patterns between weekdays and weekend days. Gulliford et al. (1990) conducted a cross-sectional study of British school children $(N=5145)$ whereby parents reported their child's bed/wake-times [159]. The authors concluded children were going to bed and waking later on weekend days compared to weekdays starting at the age of 5 years old onwards. Several other international studies incorporating larger sample sizes $(N>15,000)$ and parent-report measures show similar findings $[164,165,171]$, as do studies incorporating objective measures (e.g., accelerometers) to estimate bed/ wake times $[163,170,174]$.

\section{Diet}

Fifteen studies reported elementary school-aged children's dietary behaviors between weekend days and weekdays, with eight of these studies conducted in the U.S. [34, 175-181] Findings across U.S. based studies are consistent; children display statistically significant unfavorable diets on weekend days compared to weekdays. Baranowksi et al. (1997) reported children $(N=2984)$ had lower consumption of fruits and vegetables (FV) on weekend days compared to weekdays, with lunch time during weekdays identified as the eating occasion when children consumed the most FV [175]. This particular finding was supported by a more recent study that identified eating lunch from school was associated with higher overall diet quality compared with eating lunches from home [176]. Other studies have extended upon these findings and reported fewer FV were consumed on weekend days compared to weekdays, with children $(N=81$; age range $=6-9$ yrs. $)$ consuming a greater percentage of calories from fat and non-nutrient dense snack foods on weekend days compared to weekdays [177]. This finding is consistent with an earlier study by Cullen and colleagues showing that, in comparison to weekdays, weekend days provided significantly more high-fat practices (e.g., choosing high-fat foods, adding fat to foods, preparing foods in fat), fewer low-fat practices (e.g., choosing lower fat foods, removing skin from chicken), and a higher percent of energy from fat when 
analyzing student-reported food records completed by 4th -6 th grade children $(N=520)$ from Texas [178]. Data from the National Health and Nutrition Examination Survey (NHANES 2003-2008) was analyzed to explore school meal participation in relation to dietary quality ( $N=2376 ; 6-17$ years old). Hanson et al. (2013) obtained dietary recalls and examined differences in Healthy Eating Index (HEI) scores for breakfast only and breakfast and lunch participants. Both categories of school meal participants (i.e., breakfast only and breakfast/lunch) had higher mean weekday HEI scores for milk and vegetables, and lower HEI scores for saturated fat and sodium compared to their HEI scores for weekend days [179]. Four out of seven international studies reported statistically significant findings with children displaying unhealthy dietary behaviors, such as increased sugar intake, during weekend days compared to weekdays $[68,113,182,183]$. Three other international studies either found no difference [128, 184] or presented evidence showing favorable dietary behaviors during weekends compared to weekdays [185].

\section{Discussion}

There is a clear need for further investigation in to children's obesogenic behaviors during structured versus less-structured environments, none more so than school versus summer. The SDH presents the case that children require a structured environment to mitigate unhealthy behaviors from occurring. The evidence presented demonstrates that elementary school-aged children's obesogenic behaviors are less favorable during less-structured (i.e., weekend days) versus structured days (i.e., weekdays). The findings herein support the argument that when elementary school-aged children are exposed to environments that contain less structure, regulation, and supervision, they indulge in a host of unfavorable behaviors. Typically, summer presents 3 months of the calendar year where a less-structured environment can exist for a prolonged period of time and the observed accelerated weight-gain and losses in CRF [6, 10-17] occurring during this window demonstrates the adverse impact a less-structured environment can have on children's health and well-being.

Across all four obesogenic behaviors, $80 \%$ of the literature shows support towards the SDH. The structured nature of weekdays during the school year expose all children to various PA opportunities (e.g., recess, physical education, after-school programs, commute to school, classroom transitions/breaks) not necessarily guaranteed during weekend days. There is greater heterogeneity regarding the presence of structure and regulation on weekend days for children. This in turn may expose some children to environments where they are afforded greater autonomy over how they spend their time and/or present children with an environment that is constrained in opportunity to participate in favorable obesogenic behaviors, for example, children from low income households may not have access to PA programming and/or live in neighborhoods where crime is more prevalent, thereby limiting outdoor PA.

Nonetheless, the literature shows children's obesogenic behaviors are beneficially-regulated during weekdays during the school year. This implies that intervention efforts should be focused on instances where a lessstructured environment prevails, such as weekend days, winter breaks, and/or summer vacation. However, the authors would argue that weekend days during the school year may not merit intervention. Studies indicate that during the 9-month school year, increases in obesogenic behaviors during weekends and winter breaks do not impose the same detrimental effects on children's health that summer does [6,10-17], and this may be due, in part, to the short intermittent nature of weekend days in comparison to the prolonged duration of summer. The adverse weight and CRF outcomes associated with the presence of less-structured days (e.g., weekend days, winter breaks) are minimized or eliminated because they are interrupted by longer periods of exposure to a structured environment. For instance, over a typical 7 day week during the school year, only 2 of the 7 days are less-structured. Thus, less-structured environments, in and of themselves, may not be detrimental to weight gain and loss of CRF. Rather, we argue it is the duration of exposure to less-structured environments, as represented by summer vacation, which leads to accelerated weight gain and loss of CRF. In support, research has shown when children are exposed to a year-round structured environment interjected by short periodic breaks (e.g., year-round schools), they display a steady flat lining of BMI, particularly overweight and obese children [186]. Summer represents approximately a quarter of the calendar year, and this concentrated, largely noninterrupted exposure to a less-structured environment appears to be unfavorably impacting the health of children. This raises the question of whether summer is simply one long weekend?

In light of the SDH there are important implications to be considered by public health practitioners and researchers focused on tackling childhood overweight and obesity. A great deal of effort and resource has been allocated for intervening on and improving schools and other structured environments existing outside-ofschool time (e.g., afterschool or sport programs) [5]. Reconsidering this strategy may be worthwhile given that structured environments, by the most part, appear to be doing a decent job of mitigating adverse health outcomes from occurring in children. As mentioned previously, in comparison to school, summer is a time 
where children have more autonomy and access to fill their time with unfavorable activities, particularly in the home environment. Even when autonomy is minimized, children inherently opt for the less-healthful alternative (e.g., unhealthy snack, sedentary activity) [25, 187, 188] and the home environment represents a more open-ended and less-regulated environment for children to overindulge in unhealthy behaviors that have been associated with overweight and obesity in children [22, 23, 189]. Thus, the potential for children to adversely impact their health is much greater during summer compared to when children are in a more structured and controlled environment (e.g., school). The authors wish to reiterate that the argument herein is not for the removal of free time or unstructured time for children to play. In fact, there are several examples of existing environments that are bound within structured days (e.g., recess at schools, free time at afterschool programs, sports clubs, and summer day camps) that offer children choice(s) on how to spend their time. The day-to-day schedule and segments of these programs will differ, regardless, it is the mere presence of these programs that is providing structure to a child's day, and therefore, moderating the occurrence of unhealthy behaviors.

Given children likely spend more time at home during summer than during the school year, it is important to consider whether interventions targeting the home environment are the solution? Home-based childhood obesity interventions are limited in number and inconclusive in their effects [190] and can be a challenging and resource-consuming endeavor for practitioners [191]. Further, low-income and ethnic/racial minority households, a sub-population identified as having children most-at-risk for accelerated weight gain during summer [11], are susceptible to other economic and environmental factors (e.g., less income/access to purchase quality foods for family, safe neighborhoods for outdoor play etc. [192]) that may limit the success of home-based intervention strategies. An alternative and intuitive approach is to provide children with more opportunities and access to summer structured programs. When children spend summer days in a more-structured environment (e.g., summer day camp or program) they display favorable obesogenic behaviors compared to a less-structured environment [193, 194]. Public health practitioners and policy makers need to consider the benefit of structure to a child's day and put more effort and resources into developing strategies and partnerships with community stakeholders to provide all children equal opportunities and access to summer structured programs. Overcoming pertinent barriers (e.g., cost) that isolate children from these structured settings is of paramount importance, with a recent American Camp Association report revealing approximately $75 \%$ of youth attending camps in the U.S. were from middle-to-high income households and NonHispanic White [195].

\section{Conclusions}

In conclusion, the SDH posits that the school environment as a whole plays a protective role against the onset of unfavorable health outcomes by regulating obesogenic behaviors through its daily structure, regulation, and compulsory components. Within the last decade, researchers have identified summer as a time period where children are at risk of accelerated weight gain and losses in CRF [10-15], and the majority of this evidence stems from the U.S. Evidence showing negative health outcomes in children as a result of summer break in other countries has yet to be established, but one could speculate that a shorter summer break duration (e.g., United Kingdom, $\sim 6$ weeks) may not elicit the same detrimental impact on health outcomes in children as a longer summer break duration. Nonetheless, the authors argue that the SDH operates in a similar fashion, and the evidence from the international literature supports this with 117 out of 147 international studies showing obesogenic behaviors are more favorable on weekdays compared to weekend days. A key characteristic of both summer and weekend days is that, typically, both contexts have less consistent and formal daily structures, regulatory components, and present a more autonomous environment to children, unlike their counterparts (i.e., weekdays during the school year). However, the key element that distinguishes weekend days from summer days is the prolonged and concentrated period of time children are exposed to a less-structured environment. Summer is clearly the critical period where obesity prevention efforts need to be focused. The SDH provides a framework that can assist researchers and public health practitioners better understand the expression of obesogenic behaviors during less-structured environments, such as summer, and aid with the development of innovative observational studies and future intervention strategies.

\section{Acknowledgements \\ Not applicable. \\ Funding \\ Not applicable.}

Availability of data and materials

Data sharing is not applicable to this article as no datasets were generated or analyzed during the current study.

Authors' contributions

All authors read and approved the final manuscript.

Ethics approval and consent to participate Not applicable.

Consent for publication

Not applicable. 


\section{Competing interests}

The authors declare that they have no competing interests.

\section{Publisher's Note}

Springer Nature remains neutral with regard to jurisdictional claims in published maps and institutional affiliations.

\section{Author details}

'Department of Exercise Science, Arnold School of Public Health, University of South Carolina, 921 Assembly Street, 1st Floor Suite, Room 131, Columbia, SC 29208, USA. ${ }^{2}$ Department of Health Promotion, Education and Behavior, University of South Carolina, 915 Greene Street, Columbia, SC 29201, USA. ${ }^{3}$ Medical University of South Carolina, College of Nursing, 99 Jonathan Lucas Street, Charleston, SC 29425, USA. ${ }^{4}$ Department of Psychology, Loyola University Chicago, 1032 West Sheridan Road, Chicago, IL 60626, USA. ${ }^{5}$ The University of Texas at Austin, Lyndon B. Johnson School of Public Affairs, 2300 Red River Street, Austin, TX 78712, USA.

\section{Received: 22 May 2017 Accepted: 19 July 2017}

\section{Published online: 26 July 2017}

\section{References}

1. Cunningham SA, Kramer MR, Narayan KV. Incidence of childhood obesity in the United States. New Engl J Med. 2014;370:403-11.

2. Ogden $\mathrm{CL}$, Carroll MD, Kit BK, Flegal KM. Prevalence of childhood and adult obesity in the United States. 2011-2012. J Am Med Assoc. 2014:311:806-14.

3. Anderson J, Parker W, Steyn NP, Grimsrud A, Kolbe-Alexander T, Mciza Z, Lambert EV. Interventions on diet and physical activity: what works. Implementation of the global strategy on diet, physical activity and health. In: Summary report. Geneva: World Health Organisation; 2009.

4. Committee on Accelerating Progress in Obesity Prevention. Accelerating progress in obesity prevention: solving the weight of the nation. Washington, DC: National Academies Press; 2012.

5. Ross SE, Flynn Jl, Pate RR. What is really causing the obesity epidemic? A review of reviews in children and adults. J Sport Sci. 2015;2:1-6.

6. Economos CD, Hyatt RR, Must A, Goldberg JP, Kuder J, Naumova EN, Collins JJ, Nelson ME. Shape up Somerville two-year results: a community-based environmental change intervention sustains weight reduction in children. Prev Med. 2013:57:322-7.

7. Williams JA, Zimmerman FJ, Bell JF. Norms and trends of sleep time among US children and adolescents. JAMA Pediatr. 2013;167:55-60.

8. Falbe J, Willett WC, Rosner B, Gortmaker SL, Sonneville KR, Field AE. Longitudinal relations of television, electronic games, and digital versatile discs with changes in diet in adolescents. Am J Clin Nutr. 2014;100:1173-81.

9. Rich C, Griffiths $\sqcup$, Dezateux C. Seasonal variation in accelerometer-determined sedentary behaviour and physical activity in children: a review. Int J Behav Nutr Phys Act. 2012;9(1):49.

10. Baranowski T, O'connor T, Johnston C, Hughes S, Moreno J, Chen TA, Meltzer L, Baranowski J. School year versus summer differences in child weight gain: a narrative review. Child Obes. 2014;10(1):18-24.

11. Franckle R, Adler R, Davison K. Peer Reviewed: Accelerated Weight Gain Among Children During Summer Versus School Year and Related Racial/ Ethnic Disparities: A Systematic Review. Prev Chronic Dis. 2014;11:E101.

12. Von Hippel PT, Powell B, Downey DB, Rowland NJ. The effect of school on overweight in childhood: gain in body mass index during the school year and during summer vacation. Am J Public Health. 2007;97(4):696-702.

13. McCue M, Marlatt K, Sirard JR, Dengel DR. Examination of changes in youth diet and physical activity over the summer vacation period. Internet J Allied Health Sci Practice. 2013;11(1):1-6.

14. Chen TA, Baranowski T, Moreno JP, O'Connor TM, Hughes SO, Baranowski J, Woehler D, Kimbro RT, Johnston CA. Obesity status trajectory groups among elementary school children. BMC Public Health. 2016;16(1):1.

15. Moreno JP, Johnston CA, Woehler D. Changes in weight over the school year and summer vacation: results of a 5-year longitudinal study. J Sch Health. 2013;83(7):473-7.

16. Gutin B, Yin Z, Johnson M, Barbeau P. Preliminary findings of the effect of a 3-year after-school physical activity intervention on fitness and body fat: the medical College of Georgia Fitkid Project. Int J Pediatr Obes. 2008;3(1):3-9.

17. Yin Z, Moore JB, Johnson MH, Vernon MM, Gutin B. The impact of a 3-year after-school obesity prevention program in elementary school children. Child Obes. 2012;8(1):60-70.
18. Staiano AE, Broyles ST, Katzmarzyk PT. School term vs. school holiday: associations with Children's physical activity, screen-time, diet and sleep. Int J Environ Res Public Health. 2015;12(8):8861-70.

19. Wang YC, Vine S, Hsiao A, Rundle A, Goldsmith J. Weight-related Behaviors when children are in school versus on summer breaks: does income matter? J Sch Health. 2015;85(7):458-66.

20. Gershenson S. Do summer time-use gaps vary by socioeconomic status? Am Educ Res J. 2013;50(6):1219-48.

21. Nixon GM, Thompson JM, Han DY, Becroft DM, Clark PM, Robinson E, Waldie KE, Wild CJ, Black PN, Mitchell EA. Short sleep duration in middle childhood: risk factors and consequences. Sleep. 2008;31(1):71.

22. Appelhans BM, Fitzpatrick SL, Li H, Cail V, Waring ME, Schneider KL, Whited MC, Busch AM, Pagoto SL. The home environment and childhood obesity in low-income households: indirect effects via sleep duration and screen time. BMC Public Health. 2014;14(1):1160.

23. Avery A, Anderson C, McCullough F. Associations between children's diet quality and watching television during meal or snack consumption: A systematic review. Matern Child Nutr. 2017. doi:10.1111/mcn.12428.

24. Warren E, Parry O, Lynch R, Murphy S. 'if I don't like it then I can choose what I want': welsh school children's accounts of preference for and control over food choice. Health Promot Int. 2008:23(2):144-51.

25. Beets MW, Tilley F, Kyryliuk R, Weaver RG, Moore JB, Turner-McGrievy G. Children select unhealthy choices when given a choice among snack offerings. J Acad Nutr Diet. 2014;114(9):1440-6.

26. Caldwell LL, Smith EA. Leisure as a context for youth development and delinquency prevention. In: Pathways and crime prevention: theory, policy and practice. New York: Routledge; 2013. p. 271-97.

27. Santiago-Torres M, Adams AK, Carrel AL, LaRowe TL, Schoeller DA. Home food availability, parental dietary intake, and familial eating habits influence the diet quality of urban Hispanic children. Child Obes. 2014;10(5):408-15.

28. Beets MW, Okely A, Weaver RG, Webster C, Lubans D, Brusseau T, Carson R, Cliff DP. The theory of expanded, extended, and enhanced opportunities for youth physical activity promotion. Int J Behav Nutr Phy. 2016;13(1):120.

29. Riddoch CJ, Mattocks C, Deere K, Saunders J, Kirkby J, Tilling K, Leary SD, Blair SN, Ness AR. Objective measurement of levels and patterns of physical activity. Arch Dis Child. 2007;92(11):963-9.

30. Beck J, Chard CA, Hilzendegen C, Hill J, Stroebele-Benschop N. In-school versus out-of-school sedentary behavior patterns in US children. BMC Obesity. 2016;3(1):34

31. Golley RK, Maher CA, Matricciani L, Olds TS. Sleep duration or bedtime? Exploring the relationship between sleep habits and weight status and activity patterns. Sleep. 2011;34(10):1299-307.

32. Ralston K, Newman C, Clauson A, Guthrie J, Buzby J. The National School Lunch Program: Background, Trends, and Issues. Economic Research Report Number 61. US Department of Agriculture; 2008.

33. Mustamin R, Mamang F. Does television viewing make children obese? A review. Int J. 2016:4(2):343.

34. Matheson DM, Killen JD, Wang Y, Varady A, Robinson TN. Children's food consumption during television viewing. Am J Clin Nutr. 2004;79(6):1088-94.

35. Moher D, Liberati A, Tetzlaff J, Altman DG, Prisma Group. Preferred reporting items for systematic reviews and meta-analyses: the PRISMA statement. PLOS Med. 2009;6(7):e1000097.

36. Lee, JE, Stodden DF, Gao Z. Young Children's Energy Expenditure and Moderate-to-Vigorous Physical Activity on Weekdays and Weekends. J Phys Act Health. 2016:13(9):1013-6.

37. Hubbard K, Economos CD, Bakun P, Boulos R, Chui K, Mueller MP, Smith K, Sacheck J. Disparities in moderate-to-vigorous physical activity among girls and overweight and obese schoolchildren during school-and out-of-school time. Int J Behav Nutr Phy. 2016;13(1):1.

38. Patnode CD, Lytle LA, Erickson DJ, Sirard JR, Barr-Anderson DJ, Story M. Physical activity and sedentary activity patterns among children and adolescents: a latent class analysis approach. J Phy Act Health. 2011;8(4):457.

39. Treuth MS, Catellier DJ, Schmitz KH, Pate RR, Elder JP, McMurray RG, Blew RM, Yang S, Webber L. Weekend and weekday patterns of physical activity in overweight and normal-weight adolescent girls. Obesity. 2007;5(7):1782-8.

40. Appelhans BM, Li H. Organized sports and unstructured active play as physical activity sources in children from low-income Chicago households. Pediatr Exerc Sci. 2016:28(3):381-7.

41. Brooke HL, Atkin AJ, Corder K, Ekelund U, van Sluijs EM. Changes in timesegment specific physical activity between ages 10 and 14 years: a longitudinal observational study. J Sci Med Sport. 2016;19(1):29-34. 
42. Brooke $H L$, Corder K, Atkin AJ, van Sluijs EM. A systematic literature review with meta-analyses of within-and between-day differences in objectively measured physical activity in school-aged children. Sports Med. 2014;44(10):1427-38

43. Brusseau TA, Kulinna PH, Tudor-Locke C, Ferry M. Daily physical activity patterns of children living in an American Indian community. J Phys Act Health. 2013;10(1):48-53.

44. Brusseau TA. The intricacies of children's physical activity. J Hum Kinet. 2015: 47(1):269-75.

45. Cooper AR, Page AS, Foster LJ, Qahwaji D. Commuting to school: are children who walk more physically active? Am J Prev Med. 2003;25(4):273-6.

46. Fuemmeler BF, Anderson CB, Mâsse LC. Parent-child relationship of directly measured physical activity. Int J Behav Nutr Phy. 2011;8(1):17.

47. McMurray RG, Berry DC, Schwartz TA, Hall EG, Neal MN, Li S, Lam D. Relationships of physical activity and sedentary time in obese parentchild dyads: a cross-sectional study. BMC Public Health. 2016;16(1):24.

48. Nader PR, Bradley RH, Houts RM, McRitchie SL, O'Brien M. Moderate-tovigorous physical activity from ages 9 to 15 years. JAMA-J am Med Assoc. 2008;300(3):295-305

49. Oliver M, Schofield G, McEvoy E. An integrated curriculum approach to increasing habitual physical activity in children: a feasibility study. J School Health. 2006;76(2):74-9.

50. Sallis JF, McKenzie TL, Alcaraz JE. Habitual physical activity and healthrelated physical fitness in fourth-grade children. Ama Am J Dis Child. 1993;147(8):890-6

51. Soric M, Misigoj-Durakovic M. Physical activity levels and estimated energy expenditure in overweight and normal-weight 11-year-old children. Acta Paediatr. 2010;99(2):244-50.

52. Trost SG, Pate RR, Freedson PS, Sallis JF, Taylor WC. Using objective physical activity measures with youth: how many days of monitoring are needed? Med Sci Sports Exerc. 2000;32(2):426-31

53. Beets MW, Vogel R, Chapman S, Pitetti KH, Cardinal BJ. Parent's social support for children's outdoor physical activity: do weekdays and weekends matter? Sex Roles. 2007;56(1-2):125-31.

54. Treuth MS, Butte NF, Adolph AL, Puyau MR. A longitudinal study of fitness and activity in girls predisposed to obesity. Med Sci Sports Exerc. 2004;36(2): 198-204.

55. Atkin AJ, Sharp SJ, Harrison F, Brage S, Van Sluijs EM. Seasonal variation in Children's physical activity and sedentary time. Med Sci Sports Exerc. 2016; 48(3):449-56.

56. Comte M, Hobin E, Majumdar SR, Plotnikoff RC, Ball GD, McGavock J. Patterns of weekday and weekend physical activity in youth in 2 Canadian provinces. Appl Physiol Nutr Metab. 2013;38(2):115-9.

57. Nyberg GA, Nordenfelt AM, Ekelund U, Marcus C. Physical activity patterns measured by accelerometry in 6-to 10-yr-old children. Med Sci Sports Exerc. 2009;41(10):1842-8.

58. Gilbey H, Gilbey M. The physical activity of Singapore primary school children as estimated by heart rate monitoring. Pediatr Exerc Sci. 1995;7:26-35.

59. Antonogeorgos G, Papadimitriou A, Panagiotakos DB, Priftis KN, Nikolaidou P. Physical activity patterns and obesity status among 10-to 12-year-old adolescents living in Athens. Greece J Phys Act Health. 2010;7(5):633-40.

60. Aznar S, Naylor PJ, Silva P, Pérez M, Angulo T, Laguna M, Lara MT, LópezChicharro J. Patterns of physical activity in Spanish children: a descriptive pilot study. Child Care HIth Dev. 2011;37(3):322-8.

61. Belton S, Brady P, Meegan S, Woods C. Pedometer step count and BMI of Irish primary school children aged 6-9 years. Prev Med. 2010;50(4):189-92.

62. Brockman $\mathrm{R}$, Jago R, Fox KR. The contribution of active play to the physical activity of primary school children. Prev Med. 2010;51(2):144-7.

63. Chinapaw MJ, de Niet M, Verloigne M, De Bourdeaudhuij I, Brug J, Altenburg TM. From sedentary time to sedentary patterns: accelerometer data reduction decisions in youth. PLoS One. 2014;9(11):e111205.

64. Cleland V, Crawford D, Baur LA, Hume C, Timperio A, Salmon J. A prospective examination of children's time spent outdoors, objectively measured physical activity and overweight. Int J Obes. 2008;32(11):1685-93.

65. Corder K, Sharp SJ, Atkin AJ, Griffin SJ, Jones AP, Ekelund U, van Sluijs EM. Change in objectively measured physical activity during the transition to adolescence. B J Sports Med. 2013;49(11):730-6.

66. Corder K, Craggs C, Jones AP, Ekelund U, Griffin SJ, van Sluijs EM. Predictors of change differ for moderate and vigorous intensity physical activity and for weekdays and weekends: a longitudinal analysis. Int J Behav Nutr Phy. 2013;10(1):69.
67. De Baere S, Seghers J, Philippaerts R, De Martelaer K, Lefevre J. Intensity-and domain-specific levels of physical activity and sedentary behavior in 10-to 14-year-old children. J Phys Act Health. 2015;12(12):1543-50.

68. Duncan S, McPhee JC, Schluter PJ, Zinn C, Smith R, Schofield G. Efficacy of a compulsory homework programme for increasing physical activity and healthy eating in children: the healthy homework pilot study. Int J Behav Nutr Phy. 2011:8(1):127.

69. Duncan JS, Hopkins WG, Schofield G, Duncan EK. Effects of weather on pedometer-determined physical activity in children. Med Sci Sports Exerc. 2008;40(8):1432-8.

70. Duncan MJ, Al-Nakeeb Y, Woodfield L, Lyons M. Pedometer determined physical activity levels in primary school children from central England. Prev Med. 2007:44(5):416-20.

71. Duncan MJ, Nevill A, Woodfield L, Al-Nakeeb Y. The relationship between pedometer-determined physical activity, body mass index and lean body mass index in children. Int J Pediatr Obes. 2010;5(5):445-50.

72. Fairclough SJ, Boddy LM, Mackintosh KA, Valencia-Peris A, Ramirez-Rico E. Weekday and weekend sedentary time and physical activity in differentially active children. J Sci Med Sport. 2015;18(4):444-9.

73. Ferrari GL, Araujo TL, Oliveira L, Matsudo V, Mire E, Barreira TV, Tudor-Locke C, Katzmarzyk PT. Association between television viewing and physical activity in 10-year-old Brazilian children. J Phys Act Health. 2015;12(10):1401-8.

74. Finkelstein EA, Tan YT, Malhotra R, Lee CF, Goh SS, Saw SM. A cluster randomized controlled trial of an incentive-based outdoor physical activity program. J Pediatr. 2013;163(1):167-72.

75. Garcia-Cervantes L, D'Haese S, Izquierdo-Gomez R, Padilla-Moledo C, FernandezSantos JR, Cardon G, Veiga OL. Physical activity Coparticipation and independent mobility as correlates of objectively measured nonschool physical activity in different school grades: the UP\&DOWN study. J Phys Act Health. 2016;13(7):747-53.

76. Goodman A, Mackett RL, Paskins J. Activity compensation and activity synergy in British 8-13year olds. Prev Med. 2011;53(4):293-8.

77. Ishii K, Shibata A, Adachi M, Oka K. Association of physical activity and sedentary behavior with psychological well-being among Japanese children: a two-year longitudinal study. Percept Motor Skill. 2016;123(2):445-59.

78. Ishii K, Shibata A, Adachi M, Nonoue K, Oka K. Gender and grade differences in objectively measured physical activity and sedentary behavior patterns among Japanese children and adolescents: a cross-sectional study. BMC Public Health. 2015;15(1):1254.

79. Jago R, Sebire SJ, Turner KM, Bentley GF, Goodred JK, Fox KR, Stewart-Brown S, Lucas PJ. Feasibility trial evaluation of a physical activity and screen-viewing course for parents of 6 to 8 year-old children: Teamplay. Int J Behav Nutr Phy. 2013;10(1):31.

80. Jago R, Fox KR, Page AS, Brockman R, Thompson JL. Physical activity and sedentary behaviour typologies of 10-11 year olds. Int J Behav Nutr Phy. 2010;7(1):59.

81. Kettner S, Kobel S, Fischbach N, Drenowatz C, Dreyhaupt J, Wirt T, Koch B, Steinacker JM. Objectively determined physical activity levels of primary school children in south-west Germany. BMC Public Health. 2013;13(1):895.

82. Klasson-Heggebø L, Anderssen SA. Gender and age differences in relation to the recommendations of physical activity among Norwegian children and youth. Scandinavian J Med Sci Sports. 2003;13(5):293-8.

83. Kolle E, Steene-Johannessen J, Andersen LB, Anderssen SA. Objectively assessed physical activity and aerobic fitness in a population-based sample of Norwegian 9-and 15-year-olds. Scandinavian J Med Sci Sports. 2010;20(1):e41-7.

84. Kristensen PL, Korsholm L, Møller NC, Wedderkopp N, Andersen LB, Froberg K. Sources of variation in habitual physical activity of children and adolescents: the European youth heart study. Scandinavian J Med Sci Sports. 2008;18(3): 298-308.

85. Kruger $\mathrm{R}$, Kruger $\mathrm{H}$, Macintyre $\mathrm{U}$. The determinants of overweight and obesity among 10-to 15-year-old schoolchildren in the north West Province, South Africa-the THUSA BANA (transition and health during urbanisation of south Africans; BANA, children) study. Public Health Nutr. 2006;9(03):351-8.

86. Kwon S, Janz KF. Tracking of accelerometry-measured physical activity during childhood: ICAD pooled analysis. Int J Behav Nutr Phy. 2012;9(1):68.

87. Laguna M, Ruiz JR, Gallardo C, García-Pastor T, Lara MT, Aznar S. Obesity and physical activity patterns in children and adolescents. J Paedetr Child Health. 2013:49(11):942-9.

88. Mandich G, Burke S, Gaston A, Tucker P. The physical activity levels and sedentary Behaviors of Latino children in London (Ontario, Canada). Int J Environ Res Public Health. 2015;12(5):5528-39. 
89. Marks J, Barnett LM, Strugnell C, Allender S. Changing from primary to secondary school highlights opportunities for school environment interventions aiming to increase physical activity and reduce sedentary behaviour: a longitudinal cohort study. Int J Behav Nutr Phy. 2015;12(1):59.

90. McLure S, Summerbell C, Reilly JJ. Objectively measured habitual physical activity in a highly obesogenic environment. Child Care HIth Dev. 2009; 35(3):369-75.

91. Moreno L, Cano Cappellacci M, Orellana Zapata Y, Kain BJ. Compliance of physical activity guidelines by Chilean low-income children: difference between school and weekend days and nutritional status. Nutr Hosp. 2015; 31:2195-201.

92. Moreno L, Cano Cappellacci M, Orellana Zapata Y, Kain BJ. Direct and selfreported measures of physical activity and sedentary behaviours by weight status in school-aged children: results from ISCOLE-Kenya. Ann Hum Biol. 2015;42(3):239-47.

93. Nilsson A, Anderssen SA, Andersen LB, Froberg K, Riddoch C, Sardinha LB, Ekelund U. Between-and within-day variability in physical activity and inactivity in 9-and 15-year-old European children. Scandinavian J Med Sci Sports. 2009;19(1):10-8.

94. Okazaki K, Suzuki K, Sakamoto Y, Sasaki K. Physical activity and sedentary behavior among children and adolescents living in an area affected by the 2011 great East Japan earthquake and tsunami for 3years. Prev Med Rep. 2015:2:720-4

95. Oliver M, Duncan S, Kuch C, McPhee J, Schofield G. Prevalence of New Zealand children and adolescents achieving current physical activity and television watching recommendations. J Phys Act Health. 2012;9(2):173-87.

96. Owen CG, Nightingale CM, Rudnicka AR, Van Sluijs EM, Ekelund U, Cook DG, Whincup PH. Travel to school and physical activity levels in 9-10 year-old UK children of different ethnic origin; child heart and health study in England (CHASE). PLoS One. 2012;7(2):e30932

97. Page AS, Cooper AR, Griew P, Davis L, Hillsdon M. Independent mobility in relation to weekday and weekend physical activity in children aged 10-11 years: the PEACH project. Int J Behav Nutr Phy. 2009;6(1):2.

98. Pereira S, Gomes TN, Borges A, Santos D, Souza M, dos Santos FK, Chaves RN, Katzmarzyk PT, Maia JA. Variability and stability in daily moderate-tovigorous physical activity among 10 year old children. Int J Environ Res Public Health. 2015;12(8):9248-63.

99. Ramirez-Rico E, Hilland TA, Foweather L, Fernández-Garcia E, Fairclough SJ. Weekday and weekend patterns of physical activity and sedentary time among Liverpool and Madrid youth. Eur J Sport Sci. 2014;14(3):287-93.

100. Ridgers ND, Timperio A, Cerin E, Salmon J. Within-and between-day associations between children's sitting and physical activity time. BMC Public Health. 2015;15(1):950.

101. Sanders T, Feng X, Fahey PP, Lonsdale C, Astell-Burt T. The influence of neighbourhood green space on children's physical activity and screen time: findings from the longitudinal study of Australian children. Int J Behav Nutr Phy. 2015;12(1):126.

102. Sherar LB, Muhajarine N, Esliger DW, Baxter-Jones AD. The relationship between girls'(8-14 years) physical activity and maternal education. Ann Hum Biol. 2009;36(5):573-83.

103. Sigmund E, Sigmundová D, Bad'ura P, Vorácová J. Relationship between Czech parent and child pedometer-assessed weekday and weekend physical activity and screen time. Central European J Public Health. 2015;23:S83.

104. Sigmund E, Sigmundová D, Bad'ura P, Vorácová J. Parent-child associations in pedometer-determined physical activity and sedentary behaviour on weekdays and weekends in random samples of families in the Czech Republic. Int J Environ Res Public Health. 2014;11(7):7163-81.

105. Smith NE, Rhodes RE, Naylor PJ, McKay HA. Exploring moderators of the relationship between physical activity behaviors and television viewing in elementary school children. Am J Health Promot. 2008;22(4):231-6.

106. Steele RM, van Sluijs EM, Sharp SJ, Landsbaugh JR, Ekelund U, Griffin SJ. An investigation of patterns of children's sedentary and vigorous physical activity throughout the week. Int J Behav Nutr Phy. 2010;7(1):88.

107. Stone MR, Faulkner GE, Mitra R, Buliung RN. The freedom to explore: examining the influence of independent mobility on weekday, weekend and after-school physical activity behaviour in children living in urban and inner-suburban neighbourhoods of varying socioeconomic status. Int J Behav Nutr Phy. 2014;11(1):5.

108. Stone MR, Rowlands AV, Eston RG. Characteristics of the activity pattern in normal weight and overweight boys. Prev Med. 2009;49(2):205-8.
109. Stone MR, Stevens D, Faulkner GE. Maintaining recommended sleep throughout the week is associated with increased physical activity in children. Prev Med. 2013;56(2):112-7.

110. Tudor-Locke C, McClain JJ, Hart TL, Sisson SB, Washington TL. Expected values for pedometer-determined physical activity in youth. Res Q Exercise Sport. 2009;80(2):164-74

111. Uvacsek M, Tóth M, Ridgers N. Examining physical activity and inactivity in 9-12 years old children. Acta Phys Hung. 2011;98(3):313-20.

112. Verloigne M, Bere E, Van Lippevelde W, Maes L, Lien N, Vik FN, Brug J, Cardon G, De Bourdeaudhuij I. The effect of the UP4FUN pilot intervention on objectively measured sedentary time and physical activity in 10-12 year old children in Belgium: the ENERGY-project. BMC Public Health. 2012;12(1):805.

113. Vissers PA, Jones AP, Corder K, Jennings A, van Sluijs EM, Welch A, Cassidy A, Griffin S. Breakfast consumption and daily physical activity in 9-10-yearold British children. Public Health Nutr. 2013;16(07):1281-90.

114. Wong SH, Huang WY, He G. Longitudinal changes in objectively measured physical activity differ for weekdays and weekends among Chinese children in Hong Kong. BMC Public Health. 2015;15(1):1310.

115. Anderson YC, Wynter LE, Grant CC, Stewart JM, Cave TL, Wild CE, Derraik JG, Cutfield WS, Hofman PL. Physical activity is low in obese New Zealand children and adolescents. Sci Rep. 2017;7:41822.

116. Capio CM, Sit CH, Abernethy B, Masters RS. Fundamental movement skills and physical activity among children with and without cerebral palsy. Res Dev Disab. 2012;33(4):1235-41.

117. Gidlow CJ, Cochrane T, Davey R, Smith H. In-school and out-of-school physical activity in primary and secondary school children. J Sport Sci. 2008; 26:1411-9.

118. Ortega FB, Konstabel K, Pasquali E, Ruiz JR, Hurtig-Wennlöf A, Mäestu J, Löf M, Harro J, Bellocco R, Labayen I, Veidebaum T. Objectively measured physical activity and sedentary time during childhood, adolescence and young adulthood: a cohort study. PLoS One. 2013;8(4):e60871.

119. van Sluiis EM, Skidmore PM, Mwanza K, Jones AP, Callaghan AM, Ekelund U, Harrison F, Harvey I, Panter J, Wareham NJ, Cassidy A. Physical activity and dietary behaviour in a population-based sample of British 10-year old children: the SPEEDY study (sport, physical activity and eating behaviour: environmental determinants in young people). BMC Public Health. 2008:8(1):388.

120. Hardman CA, Horne PJ, Rowlands AV. Children's pedometer-determined physical activity during school-time and leisure-time. J Exerc Sport Fit. 2009; 7(2):129-34

121. Vandewater EA, Bickham DS, Lee JH. Time well spent? Relating television use to children's free-time activities. Pediatrics. 2006;117(2):e181-91.

122. Schmitz KH, Harnack L, Fulton JE, Jacobs DR, Gao S, Lytle LA, Coevering P. Reliability and validity of a brief questionnaire to assess television viewing and computer use by middle school children. J School Health. 2004;74(9): $370-7$.

123. Johnson L, Chen TA, Hughes SO, O'Connor TM. The association of parent's outcome expectations for child TV viewing with parenting practices and child TV viewing: an examination using path analysis. Int J Behav Nutr Phy. 2015;12(1):70.

124. Sharif I, Sargent JD. Association between television, movie, and video game exposure and school performance. Pediatrics. 2006;118(4):e1061-70.

125. Springer AE, Kelder SH, Barroso CS, Drenner KL, Shegog R, Ranjit N, Hoelscher DM. Parental influences on television watching among children living on the Texas-Mexico border. Prev Med. 2010;51(2):112-7.

126. Must A, Phillips SM, Curtin C, Anderson SE, Maslin M, Lividini K, Bandini LG Comparison of sedentary behaviors between children with autism spectrum disorders and typically developing children. Autism. 2014;18(4):376-84.

127. Kwon S, Burns TL, Levy SM, Janz KF. Breaks in sedentary time during childhood and adolescence: lowa bone development study. Med Sci Sports Exerc. 2012; 44(6): 1075

128. Bjelland M, Bergh $H$, Grydeland M, Klepp Kl, Andersen LF, Anderssen SA, Ommundsen $Y$, Lien N. Changes in adolescents' intake of sugar-sweetened beverages and sedentary behaviour: results at 8 month mid-way assessment of the HEIA study-a comprehensive, multi-component school-based randomized trial. Int J Behav Nutr Phys. 2011;8(1):63.

129. Busschaert C, Cardon G, Van Cauwenberg J, Maes L, Van Damme J, Hublet A, De Bourdeaudhuij I, De Cocker K. Tracking and predictors of screen time from early adolescence to early adulthood: a 10-year follow-up study. J Adolesc Health. 2015;56(4):440-8.

130. Carson V, Stone M, Faulkner G. Patterns of sedentary behavior and weight status among children. Pediatr Exerc Sci. 2014;26(1):95-102. 
131. Cillero $\mathbb{H}$, Jago R. Sociodemographic and home environment predictors of screen viewing among Spanish school children. J Public Health. 2011;33(3): 392-402.

132. Colley RC, Garriguet D, Janssen I, Wong SL, Saunders TJ, Carson V, Tremblay MS. The association between accelerometer-measured patterns of sedentary time and health risk in children and youth: results from the Canadian health measures survey. BMC Public Health. 2013;13(1):200.

133. Jago R, Stamatakis E, Gama A, Carvalhal IM, Nogueira H, Rosado V, Padez C. Parent and child screen-viewing time and home media environment. Am J Prev Med. 2012;43(2):150-8.

134. Jago R, Thompson JL, Sebire SJ, Wood L, Pool L, Zahra J, Lawlor DA. Crosssectional associations between the screen-time of parents and young children: differences by parent and child gender and day of the week. Int J Behav Nutr Phys Act. 2014;11(1):54

135. Jago R, Wood L, Zahra J, Thompson JL, Sebire SJ. Parental control, nurturance, self-efficacy, and screen viewing among 5-to 6-year-old children: a crosssectional mediation analysis to inform potential behavior change strategies. Child Obes. 2015;11(2):139-47.

136. Jones RA, Okely AD, Caputi P, Cliff DP. Relationships between child, parent and community characteristics and weight status among young children. Int J Pediatr Obes. 2010;5(3):256-64

137. Merchant AT, Dehghan M, Behnke-Cook D, Anand SS. Diet, physical activity, and adiposity in children in poor and rich neighbourhoods: a cross-sectional comparison. Nutr J. 2007;6(1):1

138. Mielgo-Ayuso J, Aparicio-Ugarriza R, Castillo A, Ruiz E, Avila JM, ArancetaBartrina J, Gil A, Ortega RM, Serra-Majem L, Varela-Moreiras G, GonzálezGross M. Sedentary behavior among Spanish children and adolescents: findings from the ANIBES study. BMC Public Health. 2017;17(1):94.

139. Pulsford RM, Griew P, Page AS, Cooper AR, Hillsdon MM. Socioeconomic position and childhood sedentary time: evidence from the PEACH project. Int J Behav Nutr Phys Act. 2013;10(1):105.

140. Santaliestra-Pasias AM, Mouratidou T, Verbestel V, Bammann K, Molnar D, Sieri S, Siani A, Veidebaum T, Mårild S, Lissner L, Hadjigeorgiou C. Physical activity and sedentary behaviour in European children: the IDEFICS study. Public Health Nutr. 2014;17(10):2295.

141. Sebire SJ, Jago R. Parenting quality and television viewing among 10year old children. Prev Med. 2013;56(5):348-50.

142. Sigmund E, Sigmundová D, Badura P, Kalman M, Hamrik Z, Pavelka J. Temporal trends in overweight and obesity, physical activity and screen time among Czech adolescents from 2002 to 2014: a national health behaviour in school-aged children study. Int J Environ Res Public Health. 2015;12(9):11848-68.

143. Toyran M, Ozmert E, Yurdakök K. Television viewing and its effect on physical health of schoolage children. Turkish J Pediatr. 2001;44(3):194-203.

144. Vasques C, Mota M, Correia T, Lopes V. Prevalence of overweight/obesity and its association with sedentary behavior in children. Rev Port Cardiol (Engl Ed). 2012;31(12):783-8.

145. Vorwerg Y, Petroff D, Kiess W, Blüher S. Physical activity in 3-6 year old children measured by SenseWear pro ${ }^{\oplus}$. direct accelerometry in the course of the week and relation to weight status, media consumption, and socioeconomic factors. PLoS One. 2013;8(4):e60619.

146. Wafa SW, Aziz NN, Shahril MR, Halib H, Rahim M, Janssen X. Measuring the daily activity of lying down, sitting, standing and stepping of obese children using the activPALTM activity monitor. J Trop Pediatr. 2017;63(2):98-103.

147. Cillero $\Vdash H$, Jago R, Sebire S. Individual and social predictors of screen-viewing among Spanish school children. Eur J Pediatr. 2011;170(1):93-102.

148. Granich J, Rosenberg M, Knuiman M, Timperio A. Understanding children's sedentary behaviour: a qualitative study of the family home environment. Health Educ Res. 2010;25(2):199-210.

149. Wang C, Chen P, Zhuang J. A national survey of physical activity and sedentary behavior of Chinese city children and youth using accelerometers. Res Q Exerc Sport. 2013;84(2):12-28.

150. Viner RM, Cole TJ. Television viewing in early childhood predicts adult body mass index. J Pediatr. 2005;147(4):429-35.

151. Decelis A, Jago R, Fox KR. Physical activity, screen time and obesity status in a nationally representative sample of Maltese youth with international comparisons. BMC Public Health. 2014;14(1):664.

152. Olds T, Ridley K, Dollman J. Screenieboppers and extreme screenies: the place of screen time in the time budgets of 10-13 year-old Australian children. Aust N Z J Public Health. 2006;30(2):137-42.
153. Blader JC, Koplewicz HS, Abikoff H, Foley C. Sleep problems of elementary school children: a community survey. Arch Pediatr Adol Med. 1997;151(5):473.

154. Snell EK, Adam EK, Duncan GJ. Sleep and the body mass index and overweight status of children and adolescents. Child Dev. 2007;78(1):309-23.

155. Combs D, Goodwin JL, Quan SF, Morgan WJ, Parthasarathy S. Longitudinal differences in sleep duration in Hispanic and Caucasian children. Sleep Med. 2016;18:61-6.

156. Spruyt K, Alaribe CU, Nwabara OU. Daily dynamics in sleep and behavior of young African-American children: a convoluted dyad?! Int J Psychophysiol. 2016;99:57-66.

157. Warren C, Riggs N, Pentz MA. Executive function mediates prospective relationships between sleep duration and sedentary behavior in children. Prev Med. 2016;91:82-8

158. Wong WW, Ortiz CL, Lathan D, Moore LA, Konzelmann KL, Adolph AL, Smith EO, Butte NF. Sleep duration of underserved minority children in a crosssectional study. BMC Public Health. 2013;13(1):648.

159. Gulliford MC, Price CE, Rona RJ, Chinn S. Sleep habits and height at ages 5 to 11. Arch Dis Child. 1990;65(1):119-22.

160. Duncan JS, Schofield G, Duncan EK, Rush EC. Risk factors for excess body fatness in New Zealand children. Asia Pacific J of Clin Nutr. 2008;17(1): 138-47.

161. Ekstedt M, Nyberg G, Ingre M, Ekblom Ö, Marcus C. Sleep, physical activity and $\mathrm{BMI}$ in six to ten-year-old children measured by accelerometry: a crosssectional study. Int J Behav Nutr Phy. 2013;10(1):82.

162. Altenburg TM, Chinapaw MJ, van der Knaap ET, Brug J, Manios Y, Singh AS, Longer sleep-slimmer kids: the ENERGY-project. PLoS One. 2013;8(3):e59522.

163. Wiggs L, Sparrowhawk M, Barnett AL. Parent report and actigraphically defined sleep in children with and without developmental coordination disorder; links with fatigue and sleepiness. Front Pediatr. 2016:4:81.

164. Chaput JP. Is sleep deprivation a contributor to obesity in children? Eat Weight Disord. 2016;21(1):5-11.

165. Michels N, De Henauw S, Eiben G, Hadjigeorgiou C, Hense S, Hunsberger M, Konstabel K, Molnár D, Moreno LA, Siani A, De Bourdeaudhuij I. Effect of the IDEFICS multilevel obesity prevention on children's sleep duration. Obes Rev. 2015;16(S2):68-77.

166. Zhang B, Hao Y, Zhou J, Jia F, Li X, Tang Y, Zheng H. The association between sleep patterns and overweight/obesity in Chinese children: a cross-sectional study. Neuropsych Dis Treat. 2015;11:2209.

167. Wing YK, Li SX, Li AM, Zhang J, Kong AP. The effect of weekend and holiday sleep compensation on childhood overweight and obesity. Pediatrics. 2009; 124(5):e994-e1000

168. Thivel D, Isacco L, Aucouturier J, Pereira B, Lazaar N, Ratel S, Doré E, Duché P. Bedtime and sleep timing but not sleep duration are associated with eating habits in primary school children. J Devl Beh Pediatr. 2015;36(3):158-65.

169. Touchette É, Mongrain V, Petit D, Tremblay RE, Montplaisir JY. Development of sleep-wake schedules during childhood and relationship with sleep duration. Arch Pediatr Adolesc Med. 2008;162(4):343-9.

170. Pesonen AK, Räikkönen K, Paavonen EJ, Heinonen K, Komsi N, Lahti J, Kajantie $E$, Järvenpää $A L$, Strandberg T. Sleep duration and regularity are associated with behavioral problems in 8-year-old children. Int J Behav Med. 2010;17(4):298-305.

171. Li S, Jin X, Wu S, Jiang F, Yan C, Shen X. The impact of media use on sleep patterns and sleep disorders among school-aged children in China. Sleep. 2007;30(3):361.

172. SAARENPÄÄ-HEIKKILÄ OA, Rintahaka PJ, Laippala PJ, Koivikko MJ. Sleep habits and disorders in Finnish schoolchildren. J Sleep Res. 1995;4(3):173-82.

173. BaHammam A, Bin Saeed A, Al-Faris E, Shaikh S. Sleep duration and its correlates in a sample of Saudi elementary school children. Singap Med J. 2006;47(10):875

174. Iwata S, Iwata O, lemura A, Iwasaki M, Matsuishi T. Sleep architecture in healthy 5-year-old preschool children: associations between sleep schedule and quality variables. Acta Paediatr. 2012;101(3):e110-4.

175. Baranowski T, Smith M, Hearn MD, Lin LS, Baranowski J, Doyle C, Resnicow K, Wang DT. Patterns in children's fruit and vegetable consumption by meal and day of the week. J Am Coll Nutr. 1997;16(3):216-23.

176. Au LE, Rosen NJ, Fenton K, Hecht K, Ritchie LD. Eating school lunch is associated with higher diet quality among elementary school students. J Acad Nutr Diet. 2016;11611:1817-24.

177. Hart CN, Raynor HA, Osterholt KM, Jelalian E, Wing RR. Eating and activity habits of overweight children on weekdays and weekends. Int J Pediatr Obes. 2011;6(5-6):467-72. 
178. Cullen KW, Lara KM. Children's dietary fat intake and fat practices vary by meal and day. J Am Diet Assoc. 2002;102(12):1773-8.

179. Hanson KL, Olson CM. School meals participation and weekday dietary quality were associated after controlling for weekend eating among US school children aged 6 to 17 years. J Nutr. 2013;143(5):714-21.

180. Tanasescu M, Ferris AM, Himmelgreen DA, Rodriguez N, Pérez-Escamilla R. Biobehavioral factors are associated with obesity in Puerto Rican children. J Nutr. 2000;130:1734-42.

181. Sharkey JR, Nalty C, Johnson CM, Dean WR. Children's very low food security is associated with increased dietary intakes in energy, fat, and added sugar among Mexican-origin children (6-11 y) in Texas border Colonias. BMC Pediatr. 2012; 12(1):16

182. Svensson Å, Larsson C, Eiben G, Lanfer A, Pala V, Hebestreit A, Huybrechts I, Fernández-Alvira JM, Russo P, Koni AC, De Henauw S. European children's sugar intake on weekdays versus weekends: the IDEFICS study. European J Clin Nutr. 2014;68(7):822-8.

183. Rothausen BW, Matthiessen J, Hoppe C, Brockhoff PB, Andersen LF, Tetens I. Differences in Danish children's diet quality on weekdays v. Weekend days. Public Health Nutr. 2012;15:1653-60.

184. Macdiarmid J, Loe J, Craig LC, Masson LF, Holmes B, McNeill G. Meal and snacking patterns of school-aged children in Scotland. European J Clin Nutr. 2009:63(11):1297-304.

185. Yamaguchi A, Tanaka N, Eguchi Y, Kuno K, Wakikawa N, Sarukura N, Fukinbara $\mathrm{M}$, Yamamoto S. Study on the necessary survey days for energy intake in school children assessed by 7 day survey. J Med Investig. 2012;59:111-5.

186. Alexander AG, Lyons PE. Rebound body mass index growth in year-round elementary education students of largely Hispanic descent undergoing obesity interventions. J School Health. 2016;86:181-6.

187. Epstein LH, Smith JA, Vara LS, Rodefer JS. Behavioral economic analysis of activity choice in obese children. Health Psychol. 1991;10:311.

188. Smith JA, Epstein LH. Behavioral economic analysis of food choice in obese children. Appetite. 1991;17:91-5.

189. Long DE, Gaetke LM, Perry SD, Abel MG, Clasey JL. The assessment of physical activity and nutrition in home-schooled versus public-schooled children. Pediatr Exerc Sci. 2010;22:44.

190. Showell NN, Fawole O, Segal J, Wilson RF, Cheskin L, Bleich SN, Wu Y, Lau B, Wang Y. A systematic review of home-based childhood obesity prevention studies. Pediatrics. 2013;132:193-200.

191. Foley L, Mhurchu CN, Marsh S, Epstein LH, Olds T, Dewes O, Heke I, Jiang Y, Maddison R. Screen time weight-loss intervention targeting children at home (SWITCH): process evaluation of a randomised controlled trial intervention. BMC Public Health. 2016;16:439.

192. Kumanyika S, Grier S. Targeting interventions for ethnic minority and lowincome populations. Future Child. 2006;16(1):187-207.

193. Tovar A, Lividini K, Economos CD, Folta S, Goldberg J, Must A. School's out: what are urban children doing? The summer activity study of Somerville youth (SASSY). BMC Pediatr. 2010;10(1):16.

194. Brazendale K, Beets MW, Weaver RG, Chandler IL, Randel AB, Turner-McGrievy GM, Moore JB, Huberty JL, Ward DS. Children's Moderate to Vigorous Physical Activity Attending Summer Day Camps. Am J Prev Med. 2017:53(1):78-84.

195. Fall Enrollment Summary Results. American Camping Association, 2014. http://www.acacamps.org/resource-library/research/camper-enrollmentstaffrecruitment-reports. Accessed 23 Feb 2017.

\section{Submit your next manuscript to BioMed Central and we will help you at every step:}

- We accept pre-submission inquiries

- Our selector tool helps you to find the most relevant journal

- We provide round the clock customer support

- Convenient online submission

- Thorough peer review

- Inclusion in PubMed and all major indexing services

- Maximum visibility for your research

Submit your manuscript at www.biomedcentral.com/submit
Biomed Central 